\title{
Spesifikasi Komputer Rakitan Berdasarkan Kebutuhan dan Anggaran Menggunakan Algoritma Backtracking
}

\author{
Rahmat Haryadi Kiswanto \\ Teknik Informatika \\ STIMIK Sepuluh Nopember Jayapura \\ Jayapura, Indonesia \\ e-mail: kissonetwo74@gmail.com \\ Diajukan: 6 Februari 2020; Direvisi: 1 April 2020; Diterima: 27 April 2020
}

\begin{abstract}
Abstrak
Pemilihan komputer yang baik adalah menyesuaikan dengan kebutuhan dan ketersediaan anggaran karena hal ini berhubungan dengan spesifikasi perangkat keras di dalamnya. Masih banyak masyarakat awam tidak mempunyai pengetahuan komponen komputer rakitan. Hal ini bias menjadi penyebab kurang optimalnya dalam memilih spesifikasi komputer rakitan berdasarkan kebutuhan dan ketersediaan anggaran. Sehingga perlu adanya suatu sistem yang dapat membantu masyarakat dalam memberikan informasi spesifikasi (komponen-komponen) komputer rakitan yang menyesuaikan dengan kebutuhan dan anggaran yang dimiliki calon pembeli. Pengembangan aplikasi dilakukan dengan mengamati langsung proses pembelian Komputer rakitan yang dilakukan di toko-toko komputer. Selanjutnya melakukan pengumpulan data perangkat keras komputer yang akan dijadikan spesifikasi komputer rakitan. Memilih Algoritma Backtracking dengan teknik Depth First Search dengan fungsi pembatas harga dalam proses penyusunan spesifikasi perangkat keras komputer. Pengujian dilakukan pada 4 komponen hardware untuk Paket Office dengan batas anggaran Rp 5.000.000, dan memperoleh output harga Rp 4.978 .000 dengan performa indeks 5482 dan pada Paket Grafik/Game, pengujian dilakukan pada 5 komponen hardware dengan batas anggaran Rp 8.000.000 dan memperoleh 2 pilihan output harga $R p$ 7.973.000 dan Rp 8.000.000 dengan masing-masing indeks 12749 dan 12373. Kedua pengujian menghasilkan keluaran kombinasi hardware yang tidak melebihi batas anggaran yang dimasukkan.
\end{abstract}

Kata kunci: Komputer, Backtracking, Depth First Search.

\begin{abstract}
The selection of a computer is to adjust the need and availability of budget because this is related to the hardware specification. Many ordinary people do not have knowledge about computer components, It will not lead to optimal choices in choosing computer based on need and budget. It is necessary to have system that can help them to provide information of specification of assembling computer that adjust to the needs and budgets. The development of application was carried out by directly observing the process of purchasing at computer shops. Next, collected the data of hardware for the databases of system. Chose the Backtracking Algorithm that ran a depth-first search technique with the boundary function is the budget limit. The testing was performed for 4 hardware component that arranges of the Office Package with a budget limit of $R p$ 5,000,000, and output for cost is $R p$ 4,978,000 with index performance was 5482, and the Gaming Package was performed for 5 hardware components with a budget limit of Rp 8,000,000 and the output for cost were $R p$ 7,973,000 and $R p$ 8,000,000 with index was both 12749 and 12373. The testing has shown that the output of the application was not over a budget limit.
\end{abstract}

Keywords: Computer, Backtracking, Depth First Search.

\section{Pendahuluan}

Komputer rakitan saat ini masih menjadi pilihan bagi masyarakat kelas menengah ke bawah dalam membantu mereka dalam aktivitas sehari-hari seperti pembuatan laporan pekerjaan, tugas-tugas akademik, multimedia (music, film, desain), dan lain-lain. Banyak dari perusahaan komputer ternama memproduksi komputer built up dengan berbagai tipe dan spesifikasi dengan maksud untuk menyesuaikan dengan kebutuhan pengguna. Komputer built up yang diproduksi oleh produsen ternama dapat dikatakan lebih 
mahal jika dibandingkan dengan komputer rakitan dengan spesifikasi yang sama. Di samping itu juga banyak konsumen yang menginginkan spesifikasi komputer yang sesuai dengan kebutuhan dan keinginannya. Dengan demikian alternatif komputer rakitan, dapat dijadikan pilihan untuk menentukan sendiri spesifikasi dari komputer yang ingin dibeli dengan harga lebih murah dibandingkan komputer builtup dengan spesifikasi yang hampir sama atau bahkan sama.

Untuk merakit komputer dari komponen-komponen utamanya seperti mainboard, CPU, harddisk, RAM, dan VGA card, membutuhkan pengetahuan terhadap kompatibilitas antar komponen, performa dan harga setiap komponen. Permasalahan yang terjadi tidak semua masyarakat awam mengetahui tentang komponen komputer rakitan yang baik. Selain dari itu juga banyaknya produk yang dikeluarkan oleh produsen-produsen hardware, sehingga membuat para konsumen mengalami kesulitan untuk memilih produk hardware yang sesuai dengan kebutuhan dan juga sesuai dengan anggaran. Hal ini membuat masyarakat awam lebih banyak langsung datang ke toko-toko komputer untuk menanyakan spesifikasi komputer yang sesuai dengan kebutuhannya, dan antara satu toko komputer dengan toko komputer yang lain belum tentu sama spesifikasi yang diberikan untuk kebutuhan yang sama dengan harga yang bervariasi di bawah anggaran ataupun di atas anggaran.

Dari permasalahan yang terjadi maka penelitian ini dilakukan untuk mengembangkan suatu sistem penyusunan spesifikasi komputer berdasarkan kebutuhan dan anggaran yang dimiliki konsumen. Sistem yang dibangun menggunakan Algoritma Backtracking yang merupakan algoritma Depth First Search (DFS) dengan tambahan fungsi pembatas, dengan tujuan penyusunan spesifikasi komputer tidak akan melebihi batas maksimal anggaran yang dimiliki konsumen.

Penelitian tentang penentuan spesifikasi komputer oleh [1], sistem dapat melakukan pencarian dengan menggunakan metode algoritma genetika untuk mendapatkan solusi yang optimal dengan output berupa spesifikasi PC, di mana total harga yang didapat mendekati dengan kemampuan finansial yang telah di-input-kan oleh konsumen. Penelitian yang dilakukan oleh [2] tentang penentuan spesifikasi komputer rakitan berdasarkan kebutuhan pemakai dan harga, penelitian ini menerapkan metode basis data fuzzy yang mengubah data numerik menjadi bahasa sehari-hari. Penelitian kedua ini menghasilkan suatu sistem yang dapat mempercepat proses penentuan spesifikasi yang digunakan dan menghemat anggaran yang dikeluarkan..

Penelitian terhadap penerapan terhadap metode DFS oleh [3], tentang penerapan metode DFS pada pencarian rute bus kota berbasis web mobile di Solo. Penelitian ini menghasilkan bahwa metode DFS dapat menampilkan semua solusi yang dapat terjadi sesuai dengan keinginan pemakai, baik dari segi jarak atau biaya yang paling optimal. Penelitian terhadap penerapan Algoritma Backtracking dilakukan oleh [4], yaitu perancangan aplikasi game labirin dengan menggunakan Algoritma Backtracking. Pada penelitian ini proses mencari jalan keluar permainan labirin dengan cara membentuk lintasan dari akar ke daun dan simpul-simpul yang sudah dilahirkan dinamakan simpul hidup, jika lintasan yang diperluas yang sedang dibentuk tidak mengarah ke solusi, maka simpul tersebut "dibunuh" sehingga menjadi simpul mati (dead node). Simpul yang sudah mati ini tidak akan diperluas lagi. Kemudian penelitian oleh [5], implementasi Algoritma Backtracking pada aplikasi permainan tradisional dam-daman berbasis Java desktop. Pada penelitian ini Algoritma Backtracking adalah algoritma yang berbasis pada Depth First Search (DFS) untuk mencari solusi persoalan secara lebih efisien. Algoritma Backtracking tidak memeriksa semua kemungkinan solusi yang ada, hanya pencarian yang mengarah ke solusi saja yang selalu dipertimbangkan, akibatnya waktu pencarian dapat dihemat.

\section{Metode Penelitian}

\subsection{Tahapan Penelitian}

Penelitian ini dilakukan dengan melalui beberapa tahapan yang dijabarkan sebagai berikut:

1. Studi Kelayakan

Pada tahap dilakukan studi pustaka dari hasil-hasil penelitian pada jurnal-jurnal ataupun artikel-artikel ilmiah yang dipublikasikan, khususnya yang relevan dengan permasalahan pemilihan spesifikasi komputer dan metode yang digunakan dalam penelitian ini. Selanjutnya dilakukan observasi terhadap kondisi di lapangan dengan mengunjungi beberapa toko komputer yang ada di Jayapura, terutama terkait dengan jual beli komputer rakitan. Dengan melihat proses interaksi antara user dan penjual dalam menentukan spesifikasi dan harga komputer yang akan dirakit.

2. Desain Sistem

Melakukan perancangan sistem menggunakan UML (use case diagram, class diagram, dan sequence diagram), Merancang skema database menggunakan Entity Relationship Diagram (ERD) dan merancang antarmuka pengguna untuk interaksi pengguna dengan sistem. 
3. Implementasi

ERD ditransformasikan ke dalam DBMS MySQL, mengkodekan hasil rancangan sistem dengan menerapkan Algoritma Backtracking di dalamnya menggunakan bahasa pemrograman Java.

4. Testing

Pengujian dilakukan secara white-box untuk menguji kompleksitas dari program dan blackbox untuk menguji fungsionalitas sistem berjalan dengan baik.

\subsection{Teknik Pengumpulan Data}

Data utama yang dibutuhkan adalah data komponen perangkat keras yang diambil dari beberapa website yang menyediakan harga komponen dan performa tiap komponen hardware. Data yang diperoleh ini kemudian dimasukkan ke dalam basis data yang digunakan sebagai data utama yang kemudian diolah dengan menggunakan Algoritma Backtracking untuk mendapatkan spesifikasi yang sesuai dengan anggaran dan kebutuhan konsumen.

\subsection{Instrumen Penelitian}

Dalam penelitian ini menggunakan perangkat keras dan perangkat lunak untuk mengembangkan sistem dapat dilihat pada Tabel 1 dan Tabel 2:

Tabel 1. Perangkat keras.

\begin{tabular}{cc}
\hline Item & Spesifikasi \\
\hline Laptop MacBook Air & Processor Core i5, Memori 4 GB, SSD 128 GB \\
\hline Printer & Epson L300 \\
\hline
\end{tabular}

Tabel 2. Perangkat lunak.

\begin{tabular}{cc}
\hline Item & Keterangan \\
\hline Sistem Operasi & Mac OS High Sierra \\
\hline Editor Pemrogram & Apache NetBeans IDE \\
\hline Bahasa Pemrograman Java & JDK 11 \\
\hline Basis data & MySQL \\
\hline
\end{tabular}

\subsection{Algoritma Bactracking}

Algoritma DFS merupakan algoritma pencarian dengan menelusuri node terdalam pada pohon pencarian. DFS memiliki kebutuhan memori yang sangat sederhana, hanya perlu menyimpan satu jalur dari akar ke simpul daun. Algoritma Backtracking Search merupakan varian dari DFS yang menggunakan sedikit memori. Perbedaannya pada Backtracking semua solusi dibuat dalam bentuk pohon solusi dan akan menelusuri pohon tersebut secara DFS dengan menggunakan fungsi pembatas sampai ditemukan solusi yang layak [6]. Jadi fungsi pembatas ini yang akan memberikan efisiensi pada saat penelusuran node. Misalnya pada Gambar 1 penelusuran untuk node $(1,2,5)$ tidak akan dilakukan sepenuhnya sampai di node 5 maupun ke node 6. Jika pada node 2 sudah melewati nilai dari fungsi pembatas, maka penelusuran akan langsung berganti ke node 1,3, dan seterusnya sampai solusi yang layak ditemukan atau bisa juga tidak ada solusi.

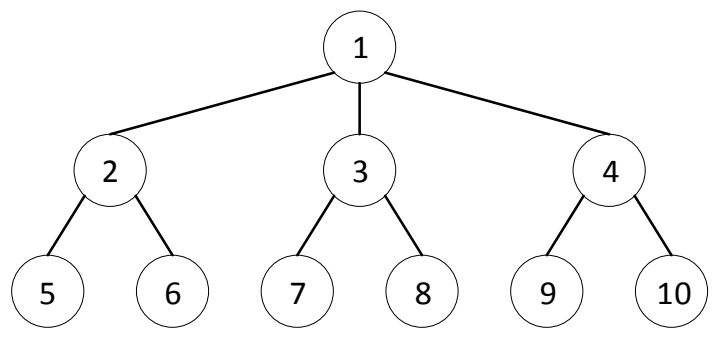

Gambar 1. Pohon solusi.

\section{Hasil dan Pembahasan}

\subsection{Desain Sistem}

Sistem yang dibuat untuk menangani pencarian spesifikasi komputer yang sesuai dengan kebutuhan dan anggaran konsumen. Dari data-data hardware komputer yang ada digunakan untuk 
dilakukannya proses kombinasi perangkat keras dengan menggunakan Algoritma Backtracking dengan batasan biaya yang dimiliki oleh konsumen dan perancangan sistem dibuat menggunakan UML.

\subsubsection{Use Case Diagram}

Use case diagram menggambarkan fungsionalitas yang diharapkan dari sebuah sistem. Sebuah use case merepresentasikan sebuah interaksi antara aktor dengan sistem. Use case diagram ditunjukkan pada Gambar 2.

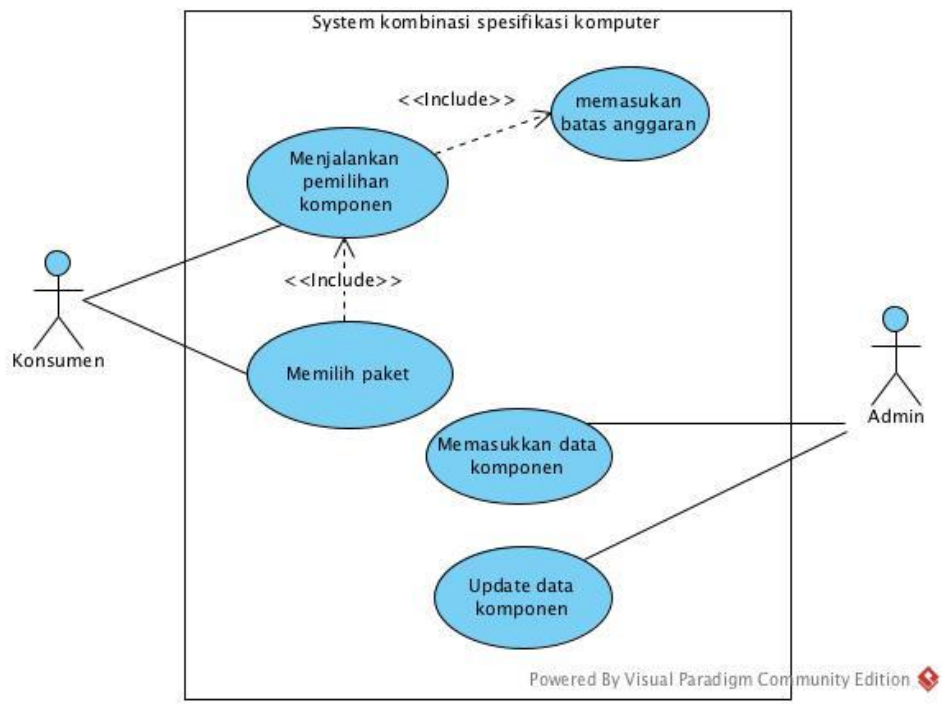

Gambar 2. Use case diagram.

\subsubsection{Activity Diagram}

Activity diagram (diagram aktivitas) menggambarkan proses yang terjadi pada pemilihan kebutuhan komputer, seperti tampak pada Gambar 3.

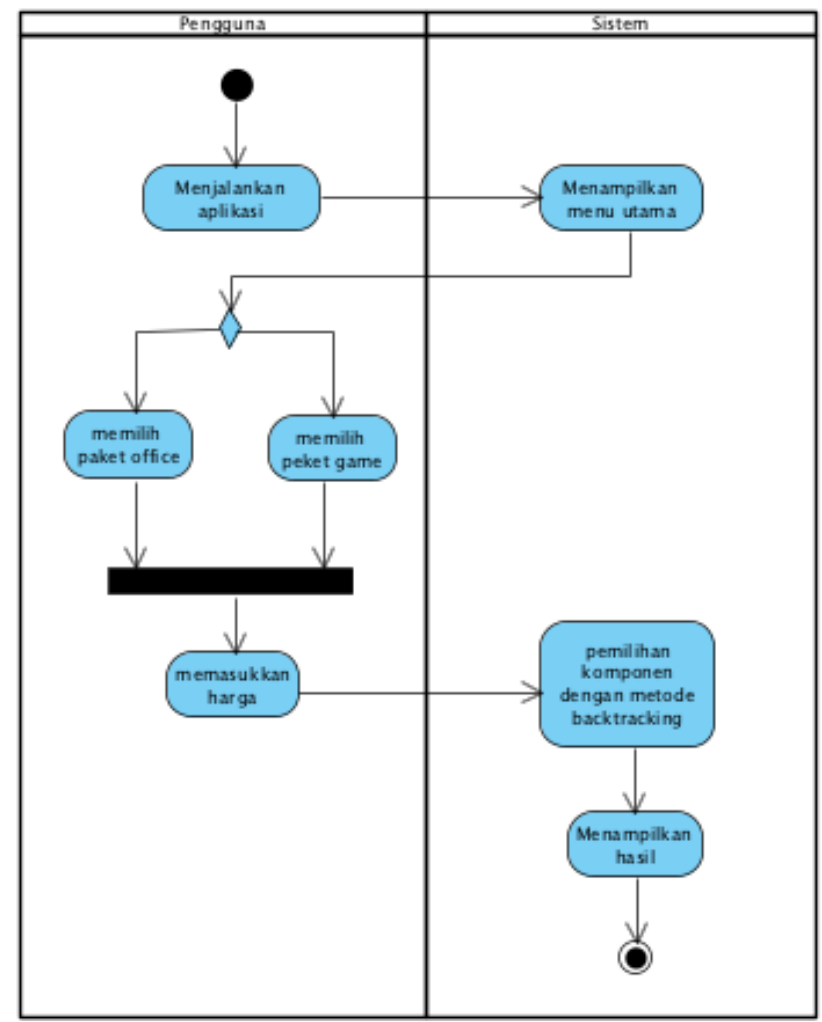

Gambar 3. Activity diagram. 


\subsubsection{Class Diagram}

Class diagram merupakan sebuah diagram statis, yang menampilkan bentuk statis dari sebuah aplikasi. Mendeskripsikan atribut dan operasi/fungsi dari suatu class. Diagram ini menunjukkan sekumpulan class, interface, asosiasi dan kolaborasi yang dikenal juga dengan sebuah diagram struktural. Gambar 4 menunjukkan class diagram pada sistem yang dibangun.

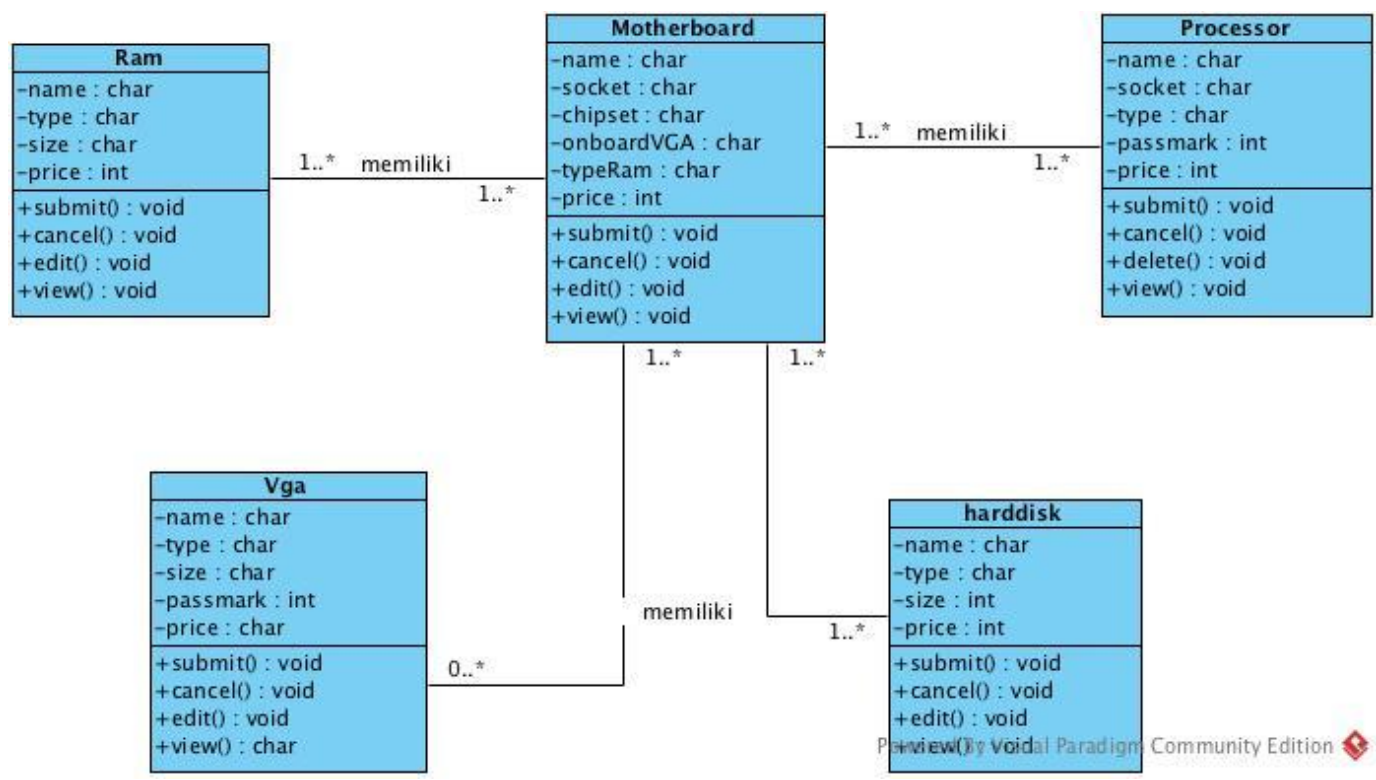

Gambar 4. Class diagram.

\subsubsection{Sequence Diagram}

Sequence diagram menggambarkan perilaku sebagai urutan pesan yang terjadi di antara sekumpulan objek [7][8]. Diagram ini juga dikatakan sebagai interaction diagram yang digunakan untuk memodelkan aspek dinamik dari sistem perangkat lunak yang dibangun. Gambar 5 merupakan sequence diagram dari sistem yang menunjukkan interaksi antar objek dalam proses pencarian kombinasi komponen komputer.

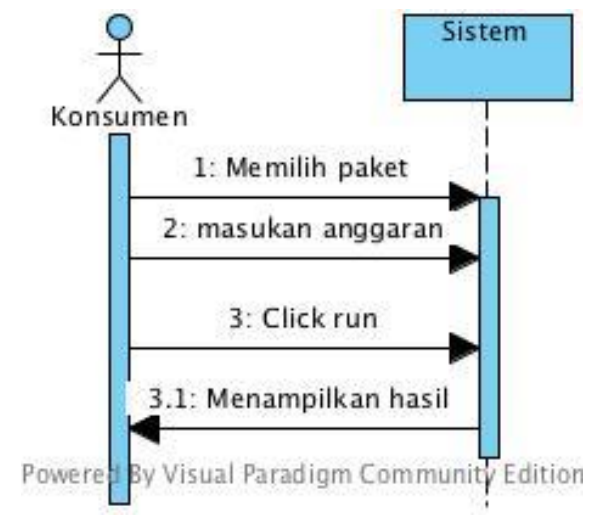

Gambar 5. Sequence diagram.

\subsection{Implementasi}

Hasil dari perancangan kemudian diimplementasikan ke dalam database dan pengodean menggunakan bahasa pemrograman Java untuk mendapatkan tampilan antarmuka yang dapat digunakan oleh admin dan pengguna, di dalam pengodean ini juga membutuhkan API database MySQL untuk dapat menghubungkan sistem ke database sehingga nantinya admin dan user dapat berinteraksi dengan sistem dan database melalui antarmuka grafis, serta menerapkan algoritma backtracking untuk proses penyusunan spesifikasinya. 


\subsubsection{Implementasi Database}

Objek-objek yang telah diidentifikasi pada perancangan sistem diimplementasikan ke dalam database dengan menggunakan DBMS MySQL. Database ini digunakan untuk penyimpanan data motherboard, processor, kartu grafis, harddisks, dan memori RAM. Tabel 3 - 7, merupakan struktur tabel di dalam database.

Tabel 3. Struktur tabel motherboard.

\begin{tabular}{ccccc}
\hline No & Nama Kolom & Tipe Data & Size & Keterangan \\
\hline 1 & id & int & 10 & Primary Key \\
\hline 2 & nama & varchar & 255 & \\
\hline 3 & socket & varchar & 255 & \\
\hline 4 & chipset & varchar & 255 & \\
\hline 5 & onboardVGA & varchar & 255 & \\
\hline 6 & type RAM & varchar & 255 & \\
\hline 7 & harga & int & 10 & \\
\hline
\end{tabular}

Tabel 4. Struktur tabel processor.

\begin{tabular}{ccccc}
\hline No & Nama Kolom & Tipe Data & Size & Keterangan \\
\hline 1 & id & int & 10 & Primary Key \\
\hline 2 & nama & varchar & 255 & \\
\hline 3 & socket & varchar & 255 & \\
\hline 4 & type & varchar & 255 & \\
\hline 5 & passmark & int & 10 & \\
\hline 6 & harga & int & 10 & \\
\hline
\end{tabular}

Tabel 5. Struktur tabel kartu grafis.

\begin{tabular}{ccccc}
\hline No & Nama Kolom & Tipe Data & Size & Keterangan \\
\hline 1 & id & int & 10 & Primary Key \\
\hline 2 & nama & varchar & 255 & \\
\hline 3 & type & varchar & 255 & \\
\hline 4 & size & varchar & 255 & \\
\hline 5 & passmark & int & 10 & \\
\hline 6 & harga & int & 10 & \\
\hline
\end{tabular}

Tabel 6. Struktur tabel harddisk.

\begin{tabular}{ccccc}
\hline No & Nama Kolom & Tipe Data & Size & Keterangan \\
\hline 1 & id & int & 10 & Primary Key \\
\hline 2 & nama & varchar & 255 & \\
\hline 3 & type & varchar & 255 & \\
\hline 4 & size & varchar & 255 & \\
\hline 5 & harga & int & 11 & \\
\hline
\end{tabular}

Tabel 7. Struktur tabel memory.

\begin{tabular}{ccccc}
\hline No & Nama Kolom & Tipe Data & Size & Keterangan \\
\hline 1 & id & int & 10 & Primary Key \\
\hline 2 & nama & varchar & 255 & \\
\hline 3 & type & varchar & 255 & \\
\hline 4 & size & varchar & 255 & \\
\hline 5 & harga & int & 11 & \\
\hline
\end{tabular}

\subsubsection{Implementasi Algoritma Backtracking}

Algoritma Backtracking merupakan algoritma DFS yang menambahkan fungsi pembatas, dalam sistem penyusunan spesifikasi perangkat keras komputer ini, yang dilakukan dengan beberapa tahapan:

1. Menyusun Urutan Kombinasi Perangkat Keras.

Perangkat keras yang ada di dalam database disusun dengan ketentuan untuk mainboard berdasarkan harga tertinggi sampai yang terendah, untuk processor dan VGA berdasarkan passmark dari yang tertinggi sampai yang terendah, untuk memory dan harddisk berdasarkan size dari yang tertinggi sampai yang terendah. Kemudian dibuat kombinasi dari masing-masing komponen perangkat keras sesuai dengan paket kebutuhan, yaitu:

a. Paket Office mempunyai urutan kombinasi mainboard, processor, memory, dan harddisk. 
b. Paket Game mempunyai 2 pilihan urutan kombinasi: (mainboard, processor, VGA, memory, harddisk) dan (mainboard, VGA, processor, memory, harddisk).

\section{Proses Backtracking}

Membangun pohon solusi untuk menyusun spesifikasi perangkat keras yang sesuai dengan budget untuk mendapatkan hasil yang optimal tidak melebihi budget. Diambil contoh untuk kebutuhan game dengan dana Rp 8.000.000, di mana dana ini menjadi fungsi pembatas. Pertama akan dilakukan pengurutan komponen pada tiap tabel perangkat keras, dengan data tiap tabel dapat dilihat pada Tabel 8 - 12:

Tabel 8. Mainboard.

\begin{tabular}{lllccc}
\hline Nama & Socket & Chipset & VGA_onboard & Type_RAM & Harga \\
\hline Asrock Taichi & LGA1151 & Intel Z370 & yes & DDR4 & 3785000 \\
\hline Asrock Killer SLI & LGA1151 & Intel Z370 & yes & DDR4 & 2485000 \\
\hline Asrock Gaming K4 & LGA1151 & Intel B250 & yes & DDR4 & 1740000 \\
\hline
\end{tabular}

Tabel 9. Processor.

\begin{tabular}{lllll}
\hline Nama & Socket & Chipset & Passmark & Harga \\
\hline Intel Core i3-8100 3,6 Ghz Cache 6 mb & LGA1151 & Intel & 8033 & 2050000 \\
\hline Intel Core i5-7400 3,0 GHz Cache 6 mb & LGA1151 & Intel & 7327 & 3045000 \\
\hline Intel Core 13-6100 3,7 GHz Cache 3 mb & LGA1151 & Intel & 5482 & 1750000 \\
\hline Intel Pentium Gold 3,7 GHz Cache 3 mb & LGA1151 & Intel & 5199 & 1005000 \\
\hline
\end{tabular}

Tabel 10. VGA.

\begin{tabular}{lllll}
\hline Nama & Type & Size & Passmark & Harga \\
\hline Asus AMD RX 570 & GDDR5 & 4 GB & 6891 & 1950000 \\
\hline Nvidia GTX 1050 & GDDR 5 & 2 GB & 4719 & 1200000 \\
\hline Asus Geforde GT 730 Kepler & GDDR5 & 2 GB & 921 & 950000 \\
\hline
\end{tabular}

Tabel 11. Memory.

\begin{tabular}{llll}
\hline Nama & Type & Size & Harga \\
\hline V-gen PC17000 & DDR4 & $4 \mathrm{~GB}$ & 698000 \\
\hline Kingston PC12800 & DDR3 & 2 GB & 323000 \\
\hline V-Gen Rescue PC12800 & DDR3 & $2 \mathrm{~GB}$ & 275000 \\
\hline
\end{tabular}

Tabel 12. Harddisk.

\begin{tabular}{llll}
\hline Nama & Type & Size & Harga \\
\hline Toshiba & SATA & $1 \mathrm{~TB}$ & 625000 \\
\hline WDC-Blue & SATA & $500 \mathrm{~GB}$ & 640000 \\
\hline WDC & SATA & $320 \mathrm{~GB}$ & 240000 \\
\hline
\end{tabular}

Bila dibuat dalam bentuk $n$-tuple untuk masing-masing komponen adalah sebagai berikut:

$$
\begin{aligned}
& M B=(M B 1, M B 2, \ldots, M B n) M B i \in S 1 i \\
& P S=(P S 1, P S 2, \ldots, P S n), P S j \in S 2 j \\
& V G=(V G 1, V G 2, \ldots, V G n), V G k \in S 3 k \\
& M M=(M M 1, M M 2 \ldots, M M n), M M l \in S 4 l \\
& H D=(H D 1, H D 2, \ldots, H D n), H D m \in S 5 m
\end{aligned}
$$

Kemudian solusi dinyatakan sebagai $S=\left(S 1_{i}, S 2_{j}, S 3_{k}, S 4_{l}, S 5_{m}\right)$. Ruang solusinya didapat dengan mengombinasikan semua kemungkinan dengan melakukan penelusuran secara $D F S$ dan hal ini akan memakan waktu cukup lama. Di sinilah metode Backtracking digunakan untuk mengurangi penelusuran secara menyeluruh pada kombinasi perangkat keras dengan menggunakan fungsi pembatas yaitu harga. Solusi dibuat dalam bentuk pohon abstrak dengan membentuk lingkaran dari akar ke daun. Aturan penelusuran secara DFS.

Simpul-simpul yang dilahirkan dinamakan simpul hidup (live node), kemudian simpul hidup diperluas dinamakan simpul E (Expansion Node), jika lintasan tidak mengarah ke solusi, maka simpul $E$ dibunuh dan simpul mati ini tidak diperluas lagi. Fungsi yang digunakan untuk membunuh simpul $E$ adalah fungsi pembatas yaitu nilai anggaran yang dimasukkan. Jika lintasan berakhir dengan simpul mati, maka 
proses diteruskan dengan membangkitkan simpul anak lainnya, bila tidak ada lagi simpul anak yang dapat dibangkitkan maka pencarian solusi lanjutkan dengan runut mundur (backtrack) ke simpul hidup terdekat (simpul orang tua). Selanjutnya simpul ini menjadi simpul $E$ yang baru.

Pencarian dimulai dari simpul $S 1_{l}$ (3.750.000) sebagai simpul orang tua, simpul anak yang pertama kali dibangkitkan adalah $S 2_{1}$ (2.050.000). Kemudian $S 1_{l}$ dan $S 2_{1}$ dijumlahkan karena masih kurang dari batas anggaran $(3.750 .000+2.050 .000<8.000 .000)$, maka penelusuran dilanjutkan dengan membangkitkan simpul $S 3_{I}(1.950 .000)$, kemudian $S 3_{1}$ dijumlahkan $(3.750 .000+2.050 .000+1.950 .000<$ 8.000.000). Penelusuran dilanjutkan kembali dengan membangkitkan simpul $S 4_{l}$ (503.000) kemudian dijumlahkan lagi $(3.750 .000+2.050 .000+1.950 .000+698.000>8.000 .000)$. Karena jumlah melebihi batas anggaran maka simpul $S 4_{1}$ dibunuh dan backtrack ke simpul $S 3_{1}$, kemudian membangkitkan simpul $S 4_{2}$ (323.000) dan dijumlahkan $(3.750 .000+2.050 .000+1.950 .000+323.000>8.000 .000)$. Di sini jumlah masih melebihi batas anggaran, maka simpul $S 3_{1}$ membunuh simpul $S 4_{2}$ dan membangkitkan simpul $S 4_{3}$ (275.000), kemudian menjumlahkan lagi $(3.750 .000+2.050 .000+1.950 .000+275.000>8.000 .000)$. Karena masih melebihi maka kembali ke simpul $S 3_{1}$ dan simpul anak untuk $S 3_{1}$ sudah habis maka simpul $S 3_{1}$ dibunuh dan kembali ke simpul $S 2_{1}$ dan membangkitkan simpul $S 3_{2}$ (1.200.000). Sekarang penelusurannya $\left(S 1_{1}, S 2_{1}, S 3_{2}\right)$ jumlahnya $(3.750 .000+2.050 .000+1.200 .000<8.000 .000)$ belum melebihi batas anggaran maka simpul anaknya dibangkitkan $S 4_{1}(6.980 .000)$ lalu dijumlahkan $(3.750 .000+$ $2.050 .000+1.200 .000+698.000<8.000 .000)$ maka simpul $S 5_{1}(625.000)$ dibangkitkan dan dijumlah $(3.750 .000+2.050 .000+1.200 .000+698.000+625.000>8.000 .000)$ melebihi maka simpul $S 5_{l}$ dibunuh dan bangkitkan simpul $S 5_{2}$ dan jumlahkan $(3.750 .000+2.050 .000+1.200 .000+698.000+640.000>$ 8.000.000) melebihi maka simpul $S 5_{2}$ dibunuh juga dan bangkitkan simpul $S 5_{3}$ dan jumlahkan (3.750.000 $+2.050 .000+1.200 .000+698.000+240.000<8.000 .000)$, sehingga ruang solusi yang didapat adalah $\left(\mathrm{S} 1_{1}, \mathrm{~S} 2_{1}, \mathrm{~S} 3_{2}, \mathrm{~S} 4_{1}, \mathrm{~S} 5_{3}\right)$ dengan total harga 7.938.000 tidak melebihi batas anggaran. Proses penelusuran ruang solusi secara backtracking dengan pohon abstrak dapat dilihat pada gambar 6 .

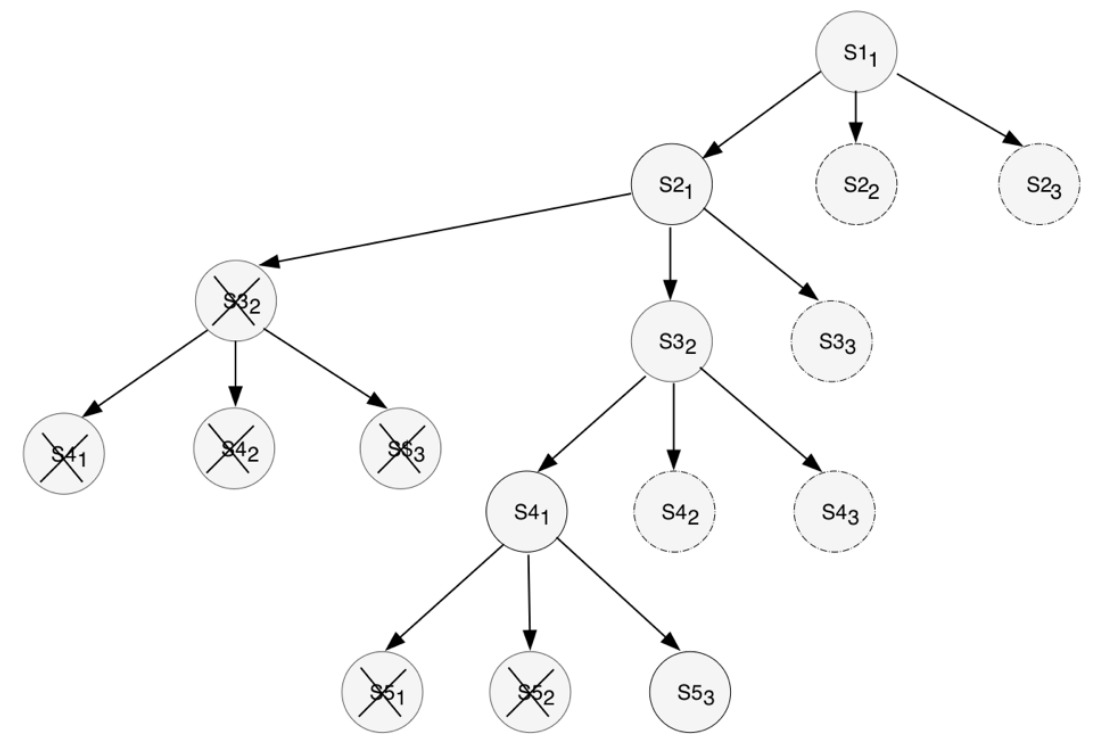

Gambar 6. Pohon abstrak penelusuran secara Bactracking.

Dengan cara yang sama juga dilakukan untuk Paket Game dengan kombinasi yang kedua dan juga untuk Paket Office.

\subsubsection{Implementasi Antarmuka Grafis}

Gambar 7 memperlihatkan tampilan menu utama dari aplikasi. Tampilan menu utama ini terdiri dari menu file dan tombol Paket Office dan Paket Grafik yang akan dijalankan jika pengguna ingin menampilkan antar muka paket. 


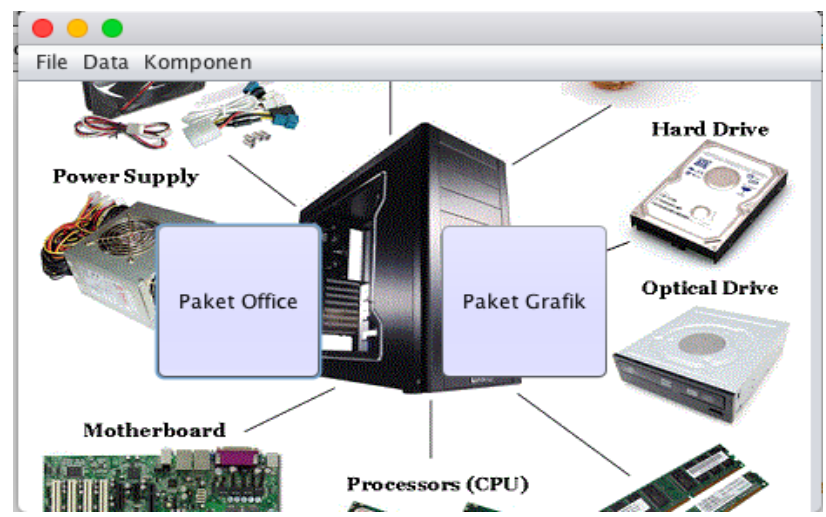

Gambar 7. Menu utama.

Gambar 8 menampilkan antarmuka Paket Office. Antarmuka grafis ini digunakan pengguna untuk mendapatkan informasi komponen utama apa saja yang optimal untuk Paket Office berdasarkan besar anggaran yang dimiliki pengguna. Antarmuka akan menampilkan komponen-komponen dengan total harga yang tidak akan melebihi anggaran yang dimasukkan. Pada Paket Office ini meniadakan komponen kartu grafis (VGA) non onboard, jadi di sini hanya akan memilih komponen motherboard yang sudah memiliki VGA onboard. Performa yang ditampilkan hanya performa dari processor.

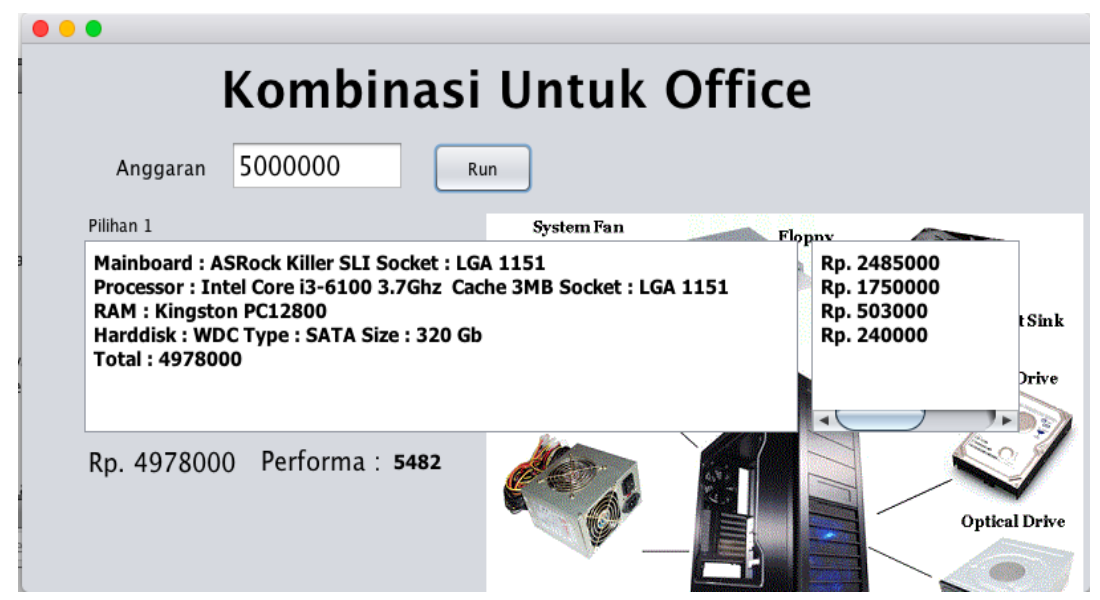

Gambar 8. Kombinasi Paket Office.

Gambar 9 Menampilkan antarmuka grafis Paket Game. Digunakan untuk mendapatkan informasi kombinasi komponen untuk Paket Game atau Grafik, susunan komponen dari atas ke bawah pada tampilan menunjukkan prioritas pilihan yang ditelusuri oleh Algoritma Backtracking. Pada paket ini menampilkan dua alternatif pilihan kombinasi. Pilihan pertama mengutamakan processor dibandingkan VGA card, sedangkan pilihan kedua mengutamakan VGA card dibandingkan processor. Performa yang ditampilkan merupakan total jumlah dari performa processor dan VGA card. 


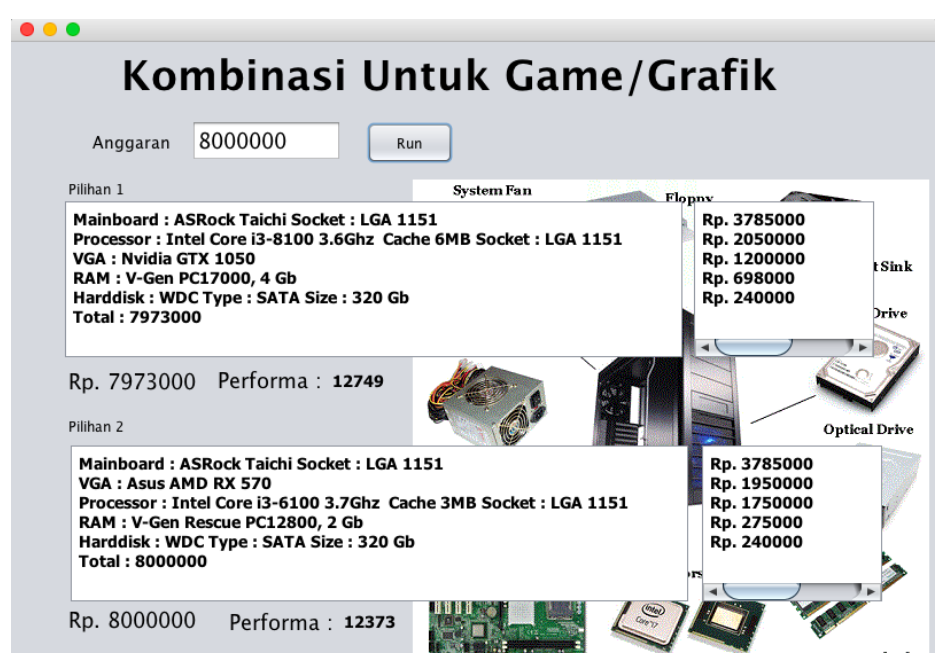

Gambar 9. Kombinasi Paket Games/Grafik.

\subsection{Pengujian}

Untuk memastikan bahwa aplikasi yang dibangun sudah berjalan dengan baik, maka perlu dilakukan pengujian terhadap aplikasi. Pengujian yang dilakukan pada penelitian ini menggunakan dua pengujian, yaitu pengujian white-box dan black-box.

\subsubsection{Pengujian White-box}

Pengujian white-box dilakukan dengan tujuan untuk mengetahui kesalahan logika dalam kode program. Digunakan untuk debugging code, menemukan kesalahan tipografi acak, dan mengungkap asumsi pemrograman yang salah [9]. Pengujian white-box pada penelitian ini memastikan bahwa semua jalur independen dijalankan untuk memastikan semua statement pada program dijalankan minimal 1 kali. Pengujian ini dilakukan dengan membuat flowgraph dari logika yang diterapkan pada kode program dan menghitung cyclomatic complexity dari flowgraph dengan rumus $V(G)=E-N+2$ [10], dan diperoleh hasil $V(G)=9$. Maka dapat dikatakan program dengan Algoritma Backtracking ini mempunyai prosedur terstruktur dengan baik dan stabil, sebagaimana dapat dilihat pada Tabel 13 yang merupakan nilai cyclomatic complexity menggunakan teori Avioso menetapkan pada mulanya standar nilai maksimum untuk cyclomatic complexity adalah 10. Namun standar nilai lain seperti 15 atau 20 juga sudah disarankan. Terlepas dari standar tersebut, jika nilai cyclomatic melebihi angka 20 maka harus dipertimbangkan bahwa hasil tersebut mengkhawatirkan untuk risiko terjadinya kecacatan [11][12].

Tabel 13. Nilai cyclomatic complexity.

\begin{tabular}{clc}
\hline Nilai CC & \multicolumn{1}{c}{ Tipe prosedur } & Tingkat risiko \\
\hline $\mathbf{1}-\mathbf{4}$ & Prosedur Sederhana & Rendah \\
\hline $\mathbf{5 - 1 0}$ & Prosedur yang terstruktur dan baik & Rendah \\
\hline $\mathbf{1 1}-\mathbf{2 0}$ & Prosedur yang lebih kompleks & Menengah \\
\hline $\mathbf{2 1}-\mathbf{5 0}$ & Prosedur yang kompleks dan kritis & Tinggi \\
\hline$>\mathbf{5 0}$ & Rentan Kesalahan & Sangat Tinggi \\
\hline
\end{tabular}

\subsubsection{Pengujian Black-box}

Black-box merupakan pengujian berdasarkan pada spesifikasi kebutuhan dan tidak perlu untuk menguji langsung pada kode program [9]. Teknik pengujian ini mengabaikan mekanisme internal atau struktur sistem dan berfokus pada output yang dihasilkan sebagai respons terhadap input yang dipilih dan kondisi eksekusi [13]. Pengujian ini murni hanya menguji pada fungsionalitas kebutuhan dari pengguna, dan untuk mengetahui apakah input dan output dari fungsionalitas berjalan dengan baik dan benar. Pengujian ini juga untuk menemukan error antara lain:

- Fungsi-fungsi yang tidak benar

- Kesalahan interface

- Kesalahan dalam struktur data

- Kesalahan kinerja

Tabel 14 merupakan pengujian black-box pada aplikasi yang dibangun. 
Tabel 14. Pengujian blackbox.

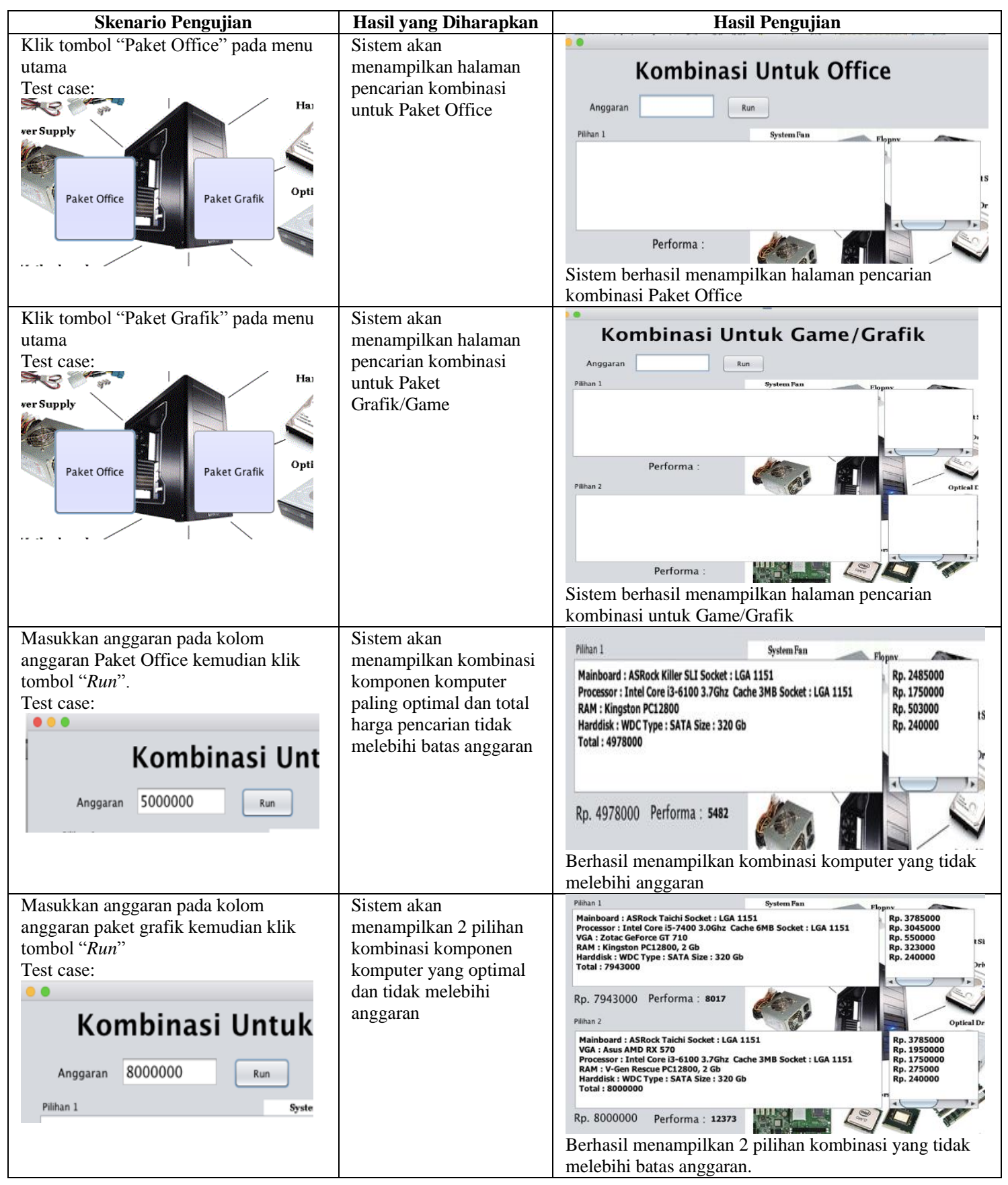

Berdasarkan hasil pengujian semua fungsionalitas berjalan dengan baik dan benar serta sistem dapat memberikan hasil kombinasi spesifikasi komputer yang sesuai dengan kebutuhan dengan tidak melebihi batas anggaran yang dimasukkan dan kompatibilitas antara komponen tetap terjaga. Hasil yang diberikan tergantung dari seberapa banyak data komponen yang dimasukkan ke dalam basis data. Semakin banyak data komponen yang dimasukkan maka semakin baik spesifikasi komputer yang diberikan oleh sistem.

\section{Kesimpulan}

1. Aplikasi ini dapat merekomendasikan spesifikasi komputer yang optimal dengan tidak melebihi anggaran yang dimiliki dan tetap menjaga kompatibilitas antara komponen dengan baik. 
2. Penyusunan spesifikasi komputer dilakukan dengan menelusuri ruang solusi kombinasi perangkat keras yang dibuat berdasarkan prioritas komponen dan menggunakan fungsi pembatas (Bounding Function) yaitu harga untuk membunuh simpul yang tidak mengarah ke solusi, sehingga kalkulasi yang tidak perlu dapat dihindari dan dapat mengurangi lamanya komputasi

3. Semua fungsionalitas sistem dapat berfungsi dengan baik setelah melalui pengujian white-box dan black-box.

4. Algoritma Backtracking ini mempunyai cyclomatic complexity yang terstruktur dan baik dengan $V(G)=9$. Dengan demikian algoritma ini sudah memperbaiki teknik DFS yang dapat mengurangi lamanya waktu komputasi.

\section{Daftar Pustaka}

[1] E. Haryanty, "Aplikasi Algoritma Genetika Dalam Menentukan Spesifikasi PC Berdasarkan Kemampuan Finansial Konsumen," Teknika, vol. 1, no. 1, pp. 21-25, 2012, doi: 10.34148/teknika.v1i1.3.

[2] M. T. Utomo and H. Mustafidah, "Penentuan Spesifikasi Komputer Berdasarkan Kebutuhan Pemakai Dan Harga Menggunakan Basis Data Fuzzy,” Juita, vol. IV, no. 1, pp. 28-36, 2016.

[3] A. Herwanto and B. E. Purnama, "Penerapan Metode Depth First Search Pada Pencarian Rute Bus Kota Berbasis Web Mobile Di Solo,” Ilm. Go Infotech, 2013.

[4] R. B. Sirait, "Perancangan Aplikasi Game Labirin Dengan Menggunakan Algoritma Backtracking," Pelita Inform. Budi Darma, vol. 5, no. 2, pp. 100-103, 2013.

[5] F. F. Coastera and A. Nomansa, "Backtracing Pada Aplikasi Permaianan Tradisional Dam-Daman," Rekursif Inform., vol. 1, no. 3, 2019.

[6] S. Russell and P. Norvig, Artificial Intelligence A Modern Approach Third Edition. New Jersey: Prentice Hall, 2010.

[7] B. Bruegge and A. H. Dutoit, Object-oriented software engineering : using UML, patterns and Java. New Jersey: Prentice Hall, 2010.

[8] T. C. Lethbridge and R. Laganiere, Object-Oriented Software Engineering. Glasgow: McGraw-Hill Education, 2005.

[9] S. Nidhra and J. Dondeti, "Black Box and White Box Testing Techniques," Int. J. Embed. Syst. Appl., vol. 2, no. 2, pp. 29-50, 2012.

[10] M. E. Khan, "Different approaches to white box testing technique for finding errors," Int. J. Softw. Eng. its Appl., vol. 2, no. 4, pp. 31-40, 2011, doi: 10.5121/ijsea.2011.2404.

[11] A. Z. Pitoyo, G. Djuwadi, and P. Yudho, "Nilai Cyclomatic Complexity Konflik Kerja terhadap Pengaruh Pimpinan dan Beban Kerja Karyawan dengan Menggunakan Model Reflektif PLS SEM," J. Pendidik., vol. 3, no. 5, pp. 648-655, 2018.

[12] H. L. P. Y. T. A. Candra, "Cyclomatic Complexity Test Design Flowgraph Registration of Emergency Installation Patients in Wava Husada Hospital Using SEM,” Int. J. Sci. Res., vol. 6, no. 8, pp. 19831987, 2017, doi: 10.21275/ART20176323.

[13] M. E. Khan, “Different Approaches to Black Box,” vol. 2, no. 4, pp. 31-40, 2011. 